\title{
URBAN SPRAWL PATTERN AND EFFECTIVE FACTORS ON THEM: THE CASE OF URMIA CITY, IRAN
}

\author{
Jamal MOHAMMADI, Asghar ZARABI, Omid MOBARAKI \\ Department of Geography and Urban Planning, University of Isfahan, Iran
}

\begin{abstract}
Urban sprawl has become a remarkable characteristic of urban development worldwide in the last decades. Urban sprawl refers to the extent of urbanization, which is a global phenomenon mainly driven by population growth and large scale migration. In developing countries like Iran, urban sprawl is taking its toll on the natural resources at an alarming pace. The purpose of this paper is to study urban growth and effective factors on them in the city of Urmia, Iran. We used quantitive data of the study area from the period between 1989 and 2007, and population censuses of Urmia. To measure the model of urban growth, Holderness and Shannon's entropy were employed. The Urmia case is interesting for several reasons: first, it is a case of very fast urban growth even for a developing country; second, it illustrates how the fastest rates of urban sprawl may correspond to middle size cities rather than to large centers. Third, it portrays a land substitution process in which agricultural land is not the primary provider of urban land which is relatively rare in urban contexts, and fourth, it also illustrates how urban sprawl may also hide important internal land uses such as the presence of agricultural plots within urban boundaries.
\end{abstract}

Key Words: planning, urban sprawl, Shannon's entropy, Urmia city, Iran

\section{Introduction}

During the past century, the world's population has been rapidly congregating in urban areas. The urban population in the world was estimated at 2.4 billion in 1995 and a doubling is expected at about the year 2025 (Yu and $\mathrm{Ng}$ 2007). According to the United Nations estimates, the population living in urban areas exceeded $50 \%$ of the world total in 2006 and will approach $60 \%$ in 2020 . Most if not virtually, all this growth is taking place in developing countries. While the explosive urban growth in the Global South is a well known phenomenon, the specific trajectories and forms of this growth are still relatively unknown. In most of the world, urban growth appears to have taken the form of disperse or sprawled patterns but case studies are needed to ascertain whether the "American model" of urban sprawl is dominant or, rather, it represents just a version of a much wider process (Zanganeh Shahraki et al. 2011). While the explosive urban growth in the Global South is a well known phenomenon, the specific trajectories and forms of this growth are still relatively unknown. In most parts of the world, urban growth appears to have taken the form of disperse or sprawled patterns, but case studies are needed to ascertain whether the "American model" of urban sprawl (Leichenko and Solecki 2005) is dominant or, rather, it represents just a version of a much wider process.

Urban sprawl is a pattern of land use exhibiting low levels of eight distinct dimensions: density, continuity, concentration, clustering, centrality, vagueness, mixed uses and proximity. Density is the average number of residential units per square mile of developable land in an urban 
area. Vagueness is the degree to which developable land has been built in close proximity to the already existing urban fabric. Concentration is the degree to which development is located disproportionately in relatively few square miles of the total urban area rather than spread evenly. Clustering is the degree to which development has been tightly bunched to minimize the amount of land in each mile of developable land occupied by residential or non-residential uses. Centrality is the degree to which residential or non-residential development (or both) is located close to the central business (CBD) of an urban area. Not clear is the extent to which an urban area is characterized by a mononuclear (as opposed to a polynuclear) pattern of development. Mixed uses means the degree to which two different land uses commonly exist within the same small area. Finally, proximity is the degree to which different land uses are close to each other across an urban area (Glaster et al. 2001). Because of these characteristics, urban sprawl is said to represent a threat for urban sustainable development since it implies an increase in the consumption of land, water, energy and other resources as well as of pollutants and waste. The environmental impacts of urban sprawl have raised concerns among planners and have stimulated other models of urban expansion such as "smart growth" (Gabriel, Faria, Moglen 2006, Litman 2007, Turner 2007) which attempt to reverse the low values of the eight dimensions stated above.

After (1961-1971), in Iran, having an increased cities' population, because of both high natural growth and large scale immigration of villagers to cities, the growth of urban form and construction did not happen based on needs but on land mongering. This led to an unorganized urban land market, especially within urban limits and the negative distribution of cities' sprawl and horizontal expansion (Athari 2000). Following the pattern of other large Iranian cities in recent years, Urmia City has had rapid and unorganized growth. This city has witnessed many population and form changes because of the population's natural growth, immigration, the spread of services, the allocation of official-political identity to this city as a province capital, the land grant by different governmental organizations within this city, the state's construction plans, state's socioeconomic and political changes and or ultimately the appropriate natural environment. This city's population has increased from 67,605 in 1956 to 583,255 in 2006. Also, in accordance with the calculations of consultant engineers, in a twentyyear interval (1986-2006), the urban area has increased from 5939 to 8577 hectares in this city. This in turn has added $95 \%$ to the initial urban area during this period (West Azerbaijan's Organization for Housing and Urban Planning, 2008).

Furthermore, these factors have resulted in the lack of land and housing, the split of urban texture, the disorganization of urban visage, the crowdedness of urban transportation (the congestion of urban traffic, especially in the city center), the conversion of appropriate agricultural lands into residential and industrial spaces, thoughtless urban constructions and the exhaustion of natural capabilities and services, the endangered urban environment which contributed to the city instability. In such conditions, it is important to improve the consequences of thoughtless urban sprawl. However, few solutions have been suggested to mitigate the consequences of this phenomenon, i.e. population growth. Strategies such as smart growth, smart management, green belts and land use planning have been proposed and implemented in other locations as possible solutions for reducing the negative impact of the urban sprawl.

\section{Background and Literature Review}

Urban sprawl is one of the main challenges in spatial planning in the $21^{\text {st }}$ century. Urban sprawl is defined as a specific form of urban development with low-density, dispersed, auto-dependent and environmentally and socially impacting characteristics (Hasse and Lathrop 2003). A whole 
range of consequences and negative implications related with this type of urban development are brought forward in literature. These include increased traffic and demand for mobility (Ewing et al. 2002, Cameron et al. 2004, Kahn 2000), land use fragmentation and loss of biodiversity (Alberti 2005), reduced landscape attractively (Sullivan and Lovell 2006) and alterations of the hydrological cycle and flooding regimes (Bronstert et al. 2002, Carlson 2004, McCuen 2003).

The urban sprawl phenomenon has been studied intensively by North American researchers (e.g. Downs 1999, Ewing et al. 2002, Hasse and Lathrop 2003, Lopez and Hynes 2003). According to Jaeger, Bertiller, Schwick, and Kienast (in press) urban sprawl denotes the extent to which an area is built-up and the extent of its dispersion in the landscape. The more the area is occupied by buildings and the more the buildings are dispersed, the higher the degree of urban sprawl is (Sabet Sarvestani and et al. 2011). Since World-War II urban sprawl has been an important feature of the urbanization process in certain developed countries such as the USA, Australia, Canada, and some European countries (Gill 2008). Currently, urban sprawl is expanding to Southern Europe (Catalán, Saurí, Serra 2008), and also to a number of developing countries such as China (Cheng, Masser 2003, Zhang 2000), India (Jothimani 1997, Lata, Sankar Rao, Krishna Prasad, Badrinath, Raghavaswamy 2001), and Turkey (Onur, Maktav, Sari, Sonmez 2009), among others.

Studies on urban sprawl have focused mainly on large cities and metropolitan areas. However, middle sized and small urban areas may be actually those experiencing the highest rates of urban growth. For instance, Weng (2001), in a paper on the Zhujiang Delta in China, concluded that the largest urban expansion in this area occurred in Dongguan, Baoan, Nanhui and Zhuhai, all of them relatively small cities located in the Eastern part of the delta. In contrast, older and larger cities, such as Guangzhou and Foshan, did not show a parallel increase in urban land. Jat, Garg, and Khare (2008) revealed that the growth in terms of urban land of Ajmer City, a medium sized city situated in Rajasthan State of India, over a period of 25 years, had tripled its population growth with an increase of the urban area from 488 ha in 1997 to 1259 ha in 2002 (Jat et al. 2008). Also in India, Sudhira, Ramachandra, and Jagadish (2004), for a city with less than 0.5 million people, reported a population increase of $54 \%$ between 1972 and 1999 , and an increase of urban area of $146 \%$ during the same period, that is, nearly three times the rate of population growth. The urban land sprawl in intermediate and small size cities continues in the developed world as in Santa Barbara, California (Herold, Goldstein, Clarke 2003), or in several Swiss municipalities (Gennaio, Hersperger, Burgi 2009), among many other examples.

While urban sprawl may be a process equally shared by developed and developing countries, specific causes and characteristics differ considerably. In the developed world, for instance, causes for urban sprawl vary from consumer preferences to new strategies of capital accumulation in cities through real estate development (Muñiz, Calatayud, García 2007). However, the study of the causes behind urban sprawl remains less explored in the developing world. More examples of how this process unfolds in specific areas are needed to explore trends, causes and consequences that enrich our understanding of the urbanization process in areas where this process is more intense.

\section{Methodology}

This study is an applied one and the methods of investigation are both descriptive and analytical. To identify the model of urban growth, quantitative models of urban planning were employed (Holderness, Shannon's entropy). Required data was collected through library 
research, field operation, master plans and different organizations. The data was analyzed by Excel and Arcview.

\section{Study area}

The city of Urmia, one of the most ancient cities in Iran, is the capital of the western Azarbaijan province. Urmia is located in a mountain area with annual precipitations of 42 to $78 \mathrm{~mm}$. The most important economic activities in Urmia are light industries (textiles, foodstuffs, paper and furniture) occupying about $45 \%$ of the active population, and tourism which benefits from the desert architecture and the historical heritage of the city. Both activities alongside with the administrative functions derived from the condition of province capital, serve as an attraction factor for many immigrants not only from the province of western Azarbaijan, but also from all Iran. Therefore, the city has experienced very rapid growth to the point that, among the Iranian cities with a population bigger than 100,000 inhabitants, Urmia had the largest growth in urban land development.

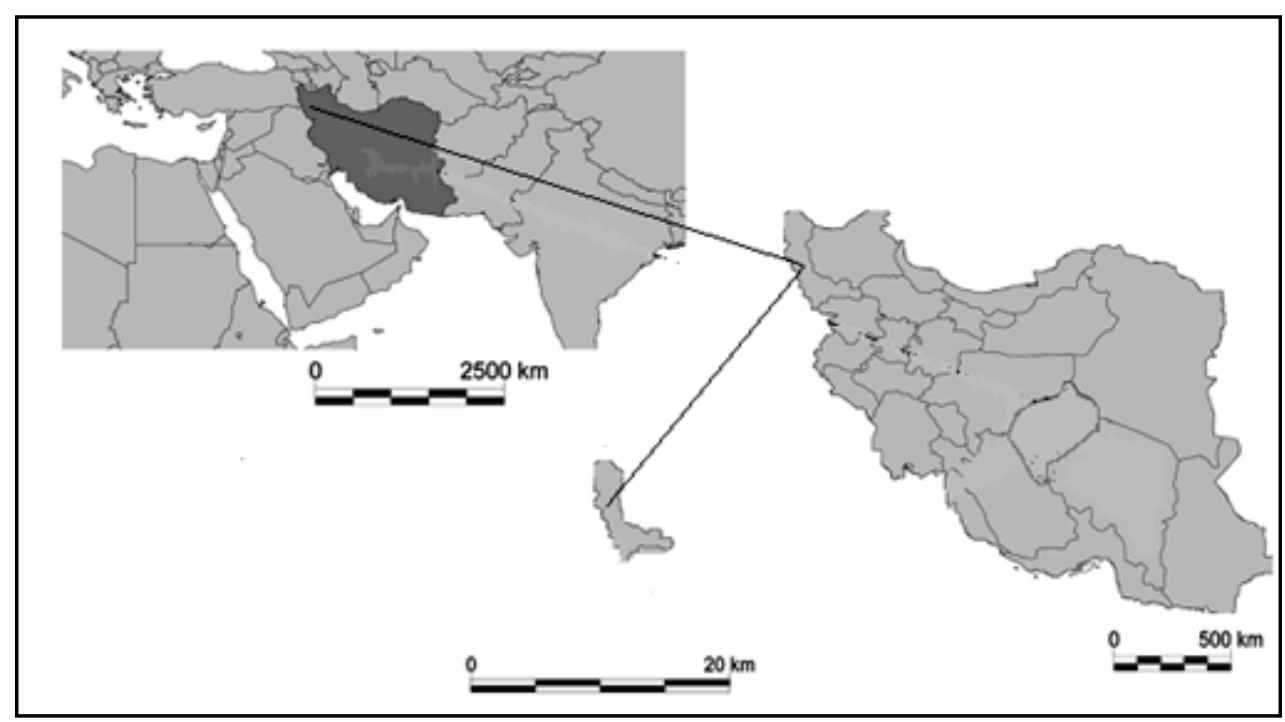

Fig. 1 - Location of study area

\section{Urban planning in Iran and Urmia}

For more than two decades (from 1976 to 2002) the urban population of Iran has seen the greatest growth and thus urban population has grown up to four times as much as the rural population. In these years, the annual growth rate of the of the urban population has been $4.3 \%$ and the rate of annual growth of the rural population has been $1.3 \%$. the characteristics of the Iranian urban system can been numerated as follows (Fanni 2006):

1. high concentration of economic and commercial investment in several big cities, especially in Tehran, and the lack of control over it. The process of urbanization in the country has been accompanied by an overconcentration of tied productive activities and economic forces in big cities, a situation which leads to a big gap between different cities, especially in the economic fields; 
2. high concentration of social, cultural, educational and welfare facilities in the above mentioned cities, which is mainly resulting from the lack of equal distribution of the capital and equipment in the totality of regions and cities.

3. Physical and spatial expansion of big cities and their irregular growth; in spite of the recent reforms (such as renovation plans), in the old cities or some of the sections of ancient cities, cities often have had not proper physical form yet and in the regional level they had not harmonious distribution spatially. This is affected by two factors: the first is the climatic and natural situation; the second is the national policy and planning.

4. Processes of urbanization lead to urban primacy, regional inequalities, centralization of political and economic power within cities and intra-urban ecological segregation and environmental crisis; this process has intensified because there is no accord on the necessary principles of urban sustainability within development (Drakakis-Smith 1995).

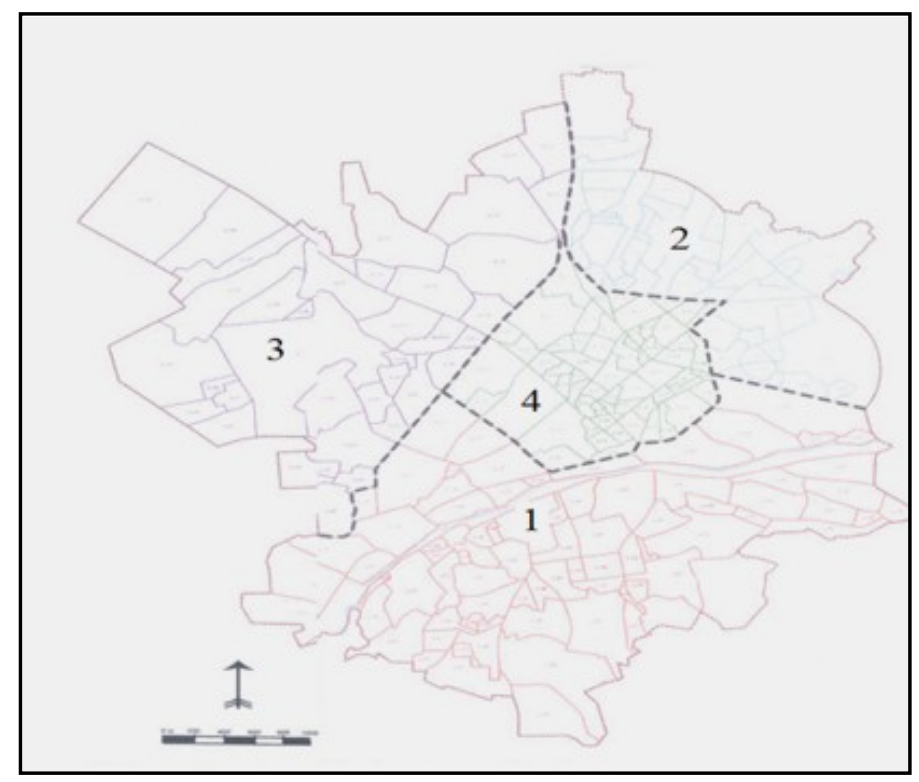

Fig. 2 - Urmia city zones

It is important to confront our data on urban growth with the realities of urban planning in Iran and in Urmia in particular. The Application of the Models to Determine the Type of urban form urban planning system of Iran is based on master or comprehensive plans. These plans are mandated by the Ministry of Housing and Urban Planning and constitute the most important instrument of the Iranian multilevel system of land-use planning. In these Master plans, maps of projected land uses are provided laying down binding provisions on how land can be used in practice. In addition, plans set urban growth and development patterns for the future based on population growth rates and on land per capita land. In this case, plans establish the boundaries between developed and non-developed zones. All types of construction are prohibited in non-development areas. However, these boundaries and limits are seldom respected and almost all Iranian cities expand beyond the determined boundaries of master plans (Zangane Shahraki et al. 2011). The first master plan of Urmia was enacted in 1972. Estimating the population growth rate of $2.5 \%$ and the population density of 100 persons per ha, this plan calculated that the city would occupy some 1760 ha of land in 1992. (Municipality 
of Urmia 2005). Comparing this number with the predicted area in the Master plan revealed a vast process of urban sprawl in this period. The second master plan of the city was issued in 1989. Acknowledging a large quantity of unused and vacant spaces inside the city, this plan sugessted not to expand and develop the city in the fringes but to follow the so-called infill development approach. Nevertheless, the boundaries envisaged in the master plan were contravened again in the following years. In the latest master plan of Urmia enacted in 2007 the predicted urban area of city for 2020 was set at 13,415 ha. In sum, the established projections of all master plans have been defeated by the dynamics of urban growth fuelled by the high number of immigrants in need of inexpensive habitation. One major problem with Iranian master plans (which is common to many other planning figures in both developed and developing worlds), is the lack of enforcement of growth control measures. Because of this lack of enforcement, newcomers usually construct and settle everywhere they want and can afford.

\section{Results and Discussions}

\section{Population growth and urban sprawl in Urmia}

According to the first official census (1956) the population of Urmia was 67,605. During the 1960 s and early 1970s, the land reform and other agricultural policies in Iran resulted in mass migration from villages to cities. Hence, at the time of the second official census (1981), the population of the city reached 164419 people. The Islamic revolution of 1979 followed by the Iran-Iraq war one year later increased further rural migration to cities. Between 1975 and 1987, the annual rate of population growth in Urmia was $5.1 \%$. In 2000 , the population reached 435200 people with an annual growth rate of $3.4 \%$. In the most recent official report (2010), the population of Urmia attained 604000 persons (Urmia Municipality 2010).

Table 1

Population, area and their increase percentage in study area.

\begin{tabular}{|c|r|r|r|r|}
\hline Year & Population & $\begin{array}{c}\text { Population increase } \\
\text { percentage } \\
(\%)\end{array}$ & $\begin{array}{c}\text { Built-up area } \\
\text { (ha) }\end{array}$ & \multicolumn{1}{c|}{$\begin{array}{c}\text { Built-up area } \\
\text { increase } \\
\text { percentage (\%) }\end{array}$} \\
\hline 1981 & 164419 & - & 1643.94 & - \\
\hline 1991 & 300746 & 54.67 & 2935.37 & 56.00452 \\
\hline 2000 & 435200 & 69.10 & 3761.54 & 78.03639 \\
\hline 2010 & 604000 & 72.05 & 5943.12 & 63.29234 \\
\hline
\end{tabular}

Source: Iranian Statistic Center (2010), Urmia Municipality (2010).

As shown in Fig. 3 and Table 1, the rate of population change is high although smaller than the increase in urban land. Employment in industrial sector is mentioned as the major reason for migrating to Urmia. As it is often the case, the lack of urban planning forced immigrants to settle in the periphery of the city where land and accommodation prices were much lower than in the city center. The economic factor or the differential land rents thus appears as a major driver of urban sprawl in Urmia. Finally, in the last studied period, Urmia presented the largest growth in built-up area. The expansion of urban land between 2000 and 2010 almost equals all urban land developed during Urmia 2000 year history. In 2009, urban uses occupied 5943.12 ha of land, and the population density had decreased to 32.78 persons per hectare. This form of development shows a disordered pattern that, among other impacts, reduced spatial solidarities. Since 1981, and in addition to rapid expansion, urban growth has remained disproportional, scattered and leapfrogged. 
An evaluation urban sprawl by use of quantities models. Holderness Model

One of the principal methods for determining urban sprawl growth is the use of Holderness Method. In 1991, John Holderness applied a method for determining urban sprawl growth and population growth. Using this method, it could be specified what is the extent of urban growth in the result of population growth and what extent in the result of urban unorganized growth. He employed land gross per capita formula (Hekmatnia and Mousavi 2006).

$$
\begin{aligned}
& \operatorname{Ln}\left(\frac{\text { population at the end of period }}{\text { population at the beginning of period }}\right)+\operatorname{Ln}\left(\frac{\text { land gross per capita at the end of period }}{\operatorname{land} \text { gross per capita at the beginning of period }}\right) \\
& =\operatorname{Ln}\left(\frac{\text { urban area at the end of period }}{\text { urban area at the beginnig of period }}\right) \\
& \qquad \operatorname{Ln}\left(\frac{577307}{344521}\right)+\operatorname{Ln}\left(\frac{47.59}{33.73}\right)=\operatorname{Ln}\left(\frac{8577}{6183}\right)
\end{aligned}
$$

$\operatorname{Ln}(1.9756)+\operatorname{Ln}(1.4109)=\operatorname{Ln}(1.3871)$

$0.5162+0.3442=0.3272$

$$
\frac{0.3442}{0.8604}+\frac{0.5162}{0.8604}=\frac{0.8604}{0.8604}
$$

$0.59+0.41=1$

Therefore, the physical growth in the Urmia City since 1989 till 2007 is $59 \%$ as a result of population growth and $41 \%$ as a result of urban growth which is related to urban sprawl and horizontal growth, which results in decreasing population's gross density and increasing urban land gross per capita.

\section{Shannon's entropy Model}

This model is used for analyzing and determining the extent of urban sprawl growth phenomenon. The general structure of this model is as follow:

$$
H=-\sum_{i=1}^{n} P i \times \operatorname{Ln}(P i)
$$

Where, $\mathrm{H}$ is the value of Shannon's entropy, $\mathrm{Pi}$ the ratio of constructed zones area (total housing density) to the total sum of zones area and $n$ the total sum of zones.

The value of the Shannon's Entropy is between 0 and $\operatorname{Ln}(\mathrm{n}) .0$ means very compact (dense) urban physical development whereas $\operatorname{Ln}(n)$ shows urban sprawl physical growth. When the value of the entropy is more than $\operatorname{Ln}(\mathrm{n})$, urban sprawl growth takes place. Tables 2 and 3 indicate that the value of entropy is 1.3738 in 1989 while the maximum value is $\operatorname{Ln}(4)=$ 1.3862. The closeness of entropy value to the maximum value suggests urban sprawl physical development. The entropy value is 1.3231 in 2007, indicating that over 20 years, physical growth has been in sprawl and incompact form. 
Calculating Shannon's Entropy for 1989 in Urmia City

\begin{tabular}{|r|r|r|r|r|}
\hline \multicolumn{1}{|c|}{ Zones } & $\begin{array}{c}\text { Constructed area } \\
\text { (Hectare) }\end{array}$ & $\mathrm{Pi}$ & $\operatorname{Ln}(\mathrm{Pi})$ & $\mathrm{Pi} \times \operatorname{Ln}(\mathrm{Pi})$ \\
\hline 1 & 745.16 & 0.2303 & -1.4683 & -0.3381 \\
\hline 2 & 634.12 & 0.1959 & -1.6301 & -0.3193 \\
\hline 3 & 921.36 & 0.2847 & -1.2536 & -0.3576 \\
\hline 4 & 934.73 & 0.2889 & -1.2416 & -0.3587 \\
\hline Total & 3235.37 & 1 & -5.5964 & -1.3738 \\
\hline
\end{tabular}

$H=1.3738$

Table 3

Calculating Shannon's Entropy for 2007 in Urmia City

\begin{tabular}{|c|r|r|r|r|}
\hline Zones & $\begin{array}{c}\text { Constructed area } \\
\text { (Hectare) }\end{array}$ & Pi & Ln(Pi) & PixLn(Pi) \\
\hline 1 & 2110.87 & 0.3701 & -0.9939 & -0.3678 \\
\hline 2 & 940.88 & 0.1649 & -1.8019 & -0.2972 \\
\hline 3 & 1714.45 & 0.3006 & -1.2019 & -0.3613 \\
\hline 4 & 936.95 & 0.1642 & -1.8061 & -0.2967 \\
\hline Total & 5703.15 & 1 & -5.8039 & -1.3231 \\
\hline
\end{tabular}

$$
H=1.3231
$$

Effective factors in sprawl growth of Urmia city

From the height point of view, the Urmia City is a short-figure city and from the perspective of urban physical loadings intensity is an open city whose main part composes of regions with a dominant aspect of one - or two-floor buildings and land units with large and average sizes. Three- and four-floor buildings are gradually accepted as usual form of construction in this city. According to the available information, of all construction permits that were issued for this city in 2006 , about $55.4 \%$ were for one to two-floor buildings, $38.7 \%$ for three or four-floor buildings and only $5.9 \%$ for five and more-floor buildings (Consultant engineers of project and logistics, 2007).

From the effective factors on the Urmia City's development, these following cases could be shown:

1) Developments in the result of immigration (immigration residence). (In this case, one could refer to the role of villages around cities in the reception of villages' immigrant);

2) Developments that are the result of city population growth ;

3) After Islamic Revolution of Iran (1979), the lack of obvious policy in the gardens within the limits of the city was one of the obstacles that forced the city to occupy the perimeter around and to develop in its marginal regions;

4) Not being able to transfer some of land uses to the outer parts of the city and to construct some of urban facilities outside the urban boundaries are some of factors that encouraged the city to extend and breached urban boundaries;

5) Activities performed legally by some offices and organizations for possessing and separating lands. Of these activities, one may name urban land offices and housing cooperatives which often meddle in urban affairs and get construction permits for the lands which have ownership issues within urban limits and authorities about this problem; 
6) Available economic, natural and legal issues/factor within urban boundaries contribute to land shortage and urban development beyond the boundaries of urban master plan;

7) The failure to change residence patterns and to grow the culture of apartment living have contributed to the occupation of spaces in a level beyond the prediction of urban master plan. Generally speaking, the city's social and economic disorganizations have led to disorganization in the city's physical development and the termination of natural and the ending process of development. Also, it is necessary to note that the specification of boundary for the-lack-of-control conditions in using urban lands have contributed to land prices increase and this was one of the main factors in developing the city beyond the boundary that is either planned by the Organization for Urban land or unplanned (in the form of immigrant habitation) (Hampanejad 2009);

8) Of the other important factors in the irregular expansion of Urmia City, one may refer to urban wandering assets which have illogically and irrationally led to land speculation and to the activities related to land trade. Besides the increase in land prices which have contributed to the emergence of new generation in the society, constructive activities which have mostly luxurious aspects, have expanded in the city; and

9) Ultimately, not paying attention to the city limits which itself is influenced by beyond-city systems, has entailed widespread margin living, the increase in housings without urban facilities, the sprawl growth of the city, towns and suburbs without urban qualities.

Effective factors on the sprawl growth of Urmia City by each factor

Table 4

\begin{tabular}{|l|l|}
\hline Social- cultural & People's inclinations and attitudes - social segregation \\
\hline Economic & Land prices-industries and workshops \\
\hline $\begin{array}{l}\text { Natural } \\
\text { Geography }\end{array}$ & $\begin{array}{l}\text { Agricultural lands and gardens-under-surface waters - around-city } \\
\text { mountains and steep slopes }\end{array}$ \\
\hline Political & $\begin{array}{l}\text { Town building projects - the submission of lands to people - the } \\
\text { specification of city limits }\end{array}$ \\
\hline Physical-spatial & $\begin{array}{l}\text { Communication networks and roads among cities - bypasses and } \\
\text { sideways }\end{array}$ \\
\hline
\end{tabular}

Source: Davoodpour and Ardalan 2008

\section{Conclusions}

Urban sprawl has increasingly become a major issue in the global trend towards urbanization. Faced not only by developed countries but also by developing countries, and by large urban centers and medium and small cities alike, urban sprawl raises social and environmental concerns at the same time that shows a multiplicity of divergent trajectories that somehow defy the dominance of homogeneous characteristics around the world. This study examined the urban sprawl of Urmia, one of the most important historical, cultural, industrial, and commercial cities in north Iran, Urmia city. In recent years, the Urmia City has had the rapid growth of population and urban area, because of so appropriate natural prerequisites (so desirable lands for agriculture and many water resources), of the development of roads and the construction of housings beside them, immigration (which led to the approach of lands around the city to the city itself (these parts joined to the city boundary), of cooperatives for town building, development and construction of disorganized settlements and urban margin living), and of the ownership issues.

As in many cities in the developing countries, sprawl in Urmia appears as an unplanned and disordered pattern which has emerged after the location of existing highways, villages and 


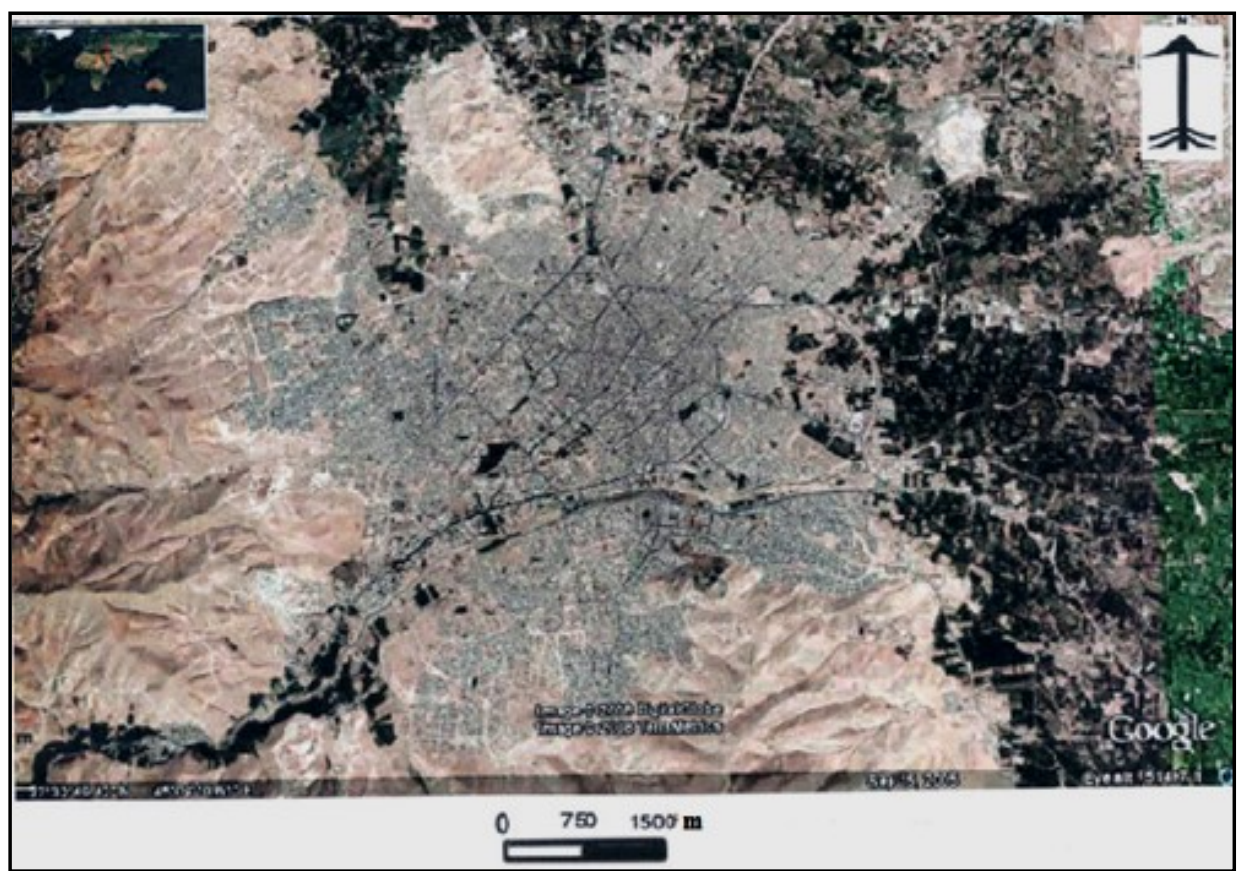

Fig. 3 - Urban growth and spawl in Urmia

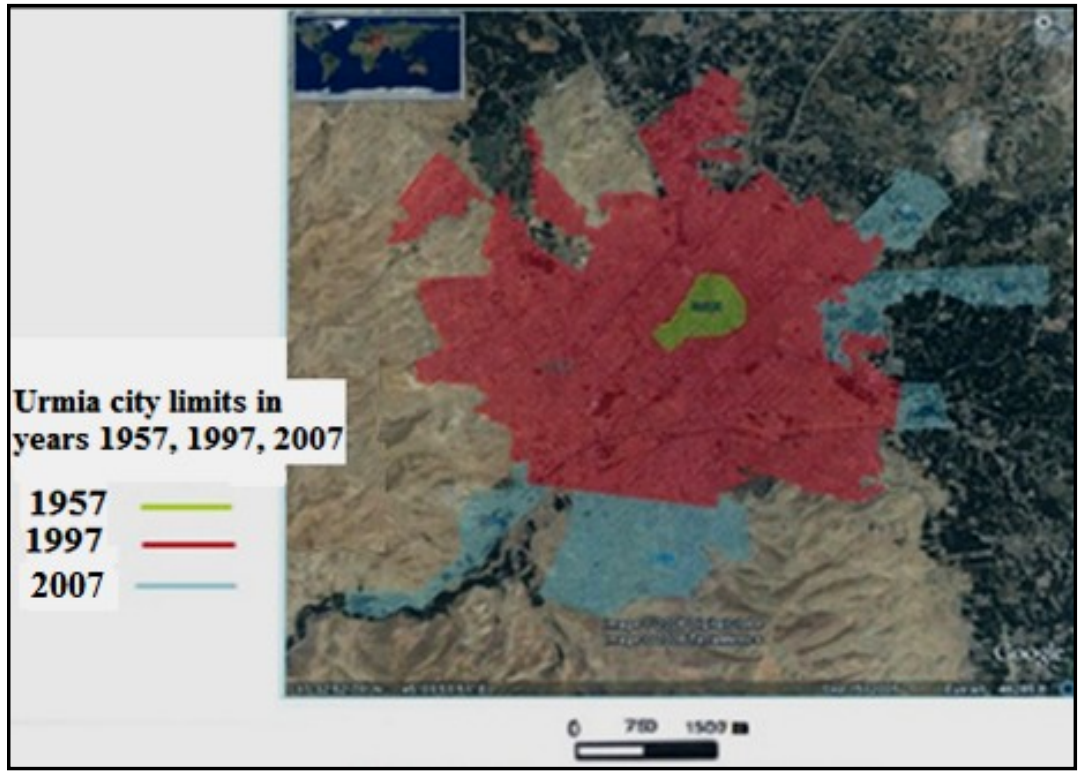

Fig. 4 - Urmia city limits in 1957, 1997 and 2007 
towns and has been created by the realities of differential land rents, industrial location, and communication networks. Also, such rapid and unplanned growth has created important problems such as lack of enough services and facilities for the residents, insecurity, increase of commuting length, and of energy consumption, and local climate change, among other matters. Finally, sprawl leaves behind numerous interstices that may be used for other functions such as agricultural land or for infilling policies, although the former appears more important than the latter. By applying quantities models, some conclusions were drawn: 1) findings resulted from Holderness Model indicate that only $59 \%$ of urban growth has been in the result of urban growth and $41 \%$ of urban growth is related to urban sprawl and horizontal growth which contribute to the gross density of population and the increase in urban gross land per capita; 2) the value of Shannon's Entropy is 1.3738 for 1989 whereas the maximum value is $\operatorname{Ln}(4)=$ 1.3862. The closeness of the entropy value to the maximum value shows the sprawl growth of urban physical development. The Shannon's Entropy is 1.3231 for 2007 , suggesting that during twenty years, physical growth has been in a sprawl and incompact manner.

According to the findings of this study, uncontrolled urban sprawl in Urmia has caused many changes in the land use of the peripheral areas. The causes of having such widespread urban sprawl should be studied in order to develop strategies for controlling the city's growth. Some of the strategies and policies that can be used for controlling the urban sprawl are: creating a regional balance to reduce migration from rural areas to urban areas or the renewal and improvement of the central-historical fabric and of the inner city of Urmia. This would cause the continuous settlement of population in these areas for living and would prevent migration from center to the suburbs. Also, the policy of infilling development can be used to provide for the future growth of the population, and for implementing strategies addressed to manage the construction in the undeveloped peripheries.

The necessity of its change and the enjoyment of strategies for more compactness of the city should be considered with respect to the direction of urban development towards more sustainability and regarding that this study's findings on urban sprawl growth have had many consequences in different economic, social and biological divisions including the exhaustion of agricultural lands around the city, the devastation and contamination of water and soil resources, the increase in the cost of delivering civic services, the increase in the time and length of inner city trips. As a result, the consumption of fossil fuels like petroleum increased, social segregation appeared, there is a lack of care about land use or irregular use of this important resource.

\section{References}

ALBERTI, M. (2005), The Effects of Urban Patterns on Ecosystem Function, Journal of International Regional Science Review, 28, 2, pp. 168-192.

ATHARI, K. (2000), Toward the Efficiency of Government's Interference in Urban Land Market, Housing Economy Quarterly, 18,Tehran, National Organization for Land and Housing, p. 36.

BRONSTERT, A., NIEHOFF, D., BURGER, G. ( 2002), Effects of Climate and Land-use Change on Storm Runoff generation: Present Knowledge and Modeling Capabilities, Hydrological Process, 16, 2, pp. 509-529.

CARLSON, T., N. (2004), Analysis and Prediction of Surface Runoff in an Urbanizing Watershed Using Satellite Imagery, Journal of the American Water Resourses Association, 40, 4, pp. 1087-1098.

CATALAN, B., SAURI, D., SERRA, P. (2008), Urban Sprawl in the Mediterranean? Patterns of Growth and Change in the Barcelona Metropolitan Region 1993-2000, Landscape 
and Urban Planning, 85, pp.174-184.

CHENG, J., MASSER, I. (2003), Urban Growth Pattern Modeling: A Case Study of

Wuhan city, PR China, Landscape and Urban Planning, 62, pp.199 - 217. DAVOUDPOUR, Z., ARDALAN, D. (2008), The Investigation of Effective Factors on Great and Middle Cities, City Identity Magazine, 3,3, Teheran, p. 56. DRAKAKIS-SMITH, D. (1995), Third World Cities: Sustainable Urban Development I, Urban Studies, 32, 4-5, pp. 659-677. EWING, R., PENDALL, R., CHEN, D. (2002), Measuring Sprawl and its Impact, Smart Growth America, Washington D.C. FANNI, Z. (2006), Cities and urbanization in Iran after the Islamic Revolution, Cities, 23 , 6, pp. 407-411.

GENNAIO, M., HERSPERGER, A., M., BURGI, M. (2009), Containing Urban Sprawl Devaluating Effectiveness of Urban Growth Boundaries set by the Swiss Land Use Plan, Land Use Policy, 26, pp. 224-232. GILL, J. (2008), The Effect of Urban Sprawl on Sydney's Peri-Urban Agricultural Region, Society, Environmental Policy and Sustainability. HASSE, J., E., LATHROP, R., G.(2003), Land Resource Impact Indicators of Urban Sprawl, Journal of Applied Geography, 23, pp.159-175. HEKMATNIA, H., MOUSAVI, M. (2006), The Application of Model in Geography with the

Emphasis on Urban and Regional Planning (1 $1^{\text {st }}$ ed.), Yazd, Elm-e-Novin Publications, p.129. HEROLD, M., GOLDSTEIN, N., C., CLARKE, K., C. (2003), The Spatio-temporal form of Urban Growth: Measurement, Analysis and Modeling, Remote Sensing of Environment, 86, pp. 286-302.

IRAN'S STATISTICS CENTER (1956, 1966, 1976, 1986, 1996, 2006), The Results of Public Census of People and Housing.

JAT, M., K., GARG, P., K., KHARE, D. (2008), Monitoring and Modeling of Urban Sprawl Using Remote Sensing and GIS Techniques, International Journal of Applied Earth Observation and Geo Information, 10, 1, pp. 26- 43.

JOTHIMANI, P. (1997), Operational Urban Sprawl Monitoring Using Satellite Remote Sensing: Excerpts from the studies of Ahmedabad, Vadodara and Surat, India, Paper presented at 18th Asian Conference on Remote Sensing, held during October 20-24, Malaysia. LATA, K. M., SANKAR, RAO, C., H., KRISHNA, PRSAD, V., BADRINATH, K., V., S., RAGHAVASWAMY (2001), Measuring Urban Sprawl: A Case Study of Hyderabad,www. Geo spatialworld. Net, GIS Development, 5,12, pp. 1-4. LEICHENKO, R., M., SOLECKI, W., D. (2005), Exporting the American dream. The Globalization of Suburban Consumption Landscapes, Regional Studies, 39, pp.241-253. McCUEN, R.,H. (2003), Smart Growth: Hydrologic Perspective, Journal of Professional Issues in Engineering, 129, 3, pp 151-154. MUNICIPALITY of URMIA (2005), The Brief report of New Master plan of Urmia, 3, Iran, Urmia.

MUNICIPALITY of URMIA (2009), Master and Detailed Plan of Urmia City, Iran, Urmia. MUNIZ, I., CALATAYUD, D., GARCIA, M., A. (2007), Sprawl Causes and Effects of Urban Dispersion, in F. Indovina (Eds.), The low Density City, Barcelona, Diputació de Barcelona, pp. 307-347.

ONUR, I., MAKTAV, D., SARI, M., SONMEZ, N., K. (2009), Change Detection of Land Cover and Land use Using Remote Sensing and GIS. A Case Study in Kemer, Turkey, International Journal of Remote Sensing, 30, 7, pp.1749 - 1757.

OTHIMANI, P. (1997), Operational Urban Sprawl Monitoring Using Satellite Remote Sensing: Excerpts from the studies of Ahmedabad, Vadodara and Surat, India, Paper presented at 18th Asian Conference on Remote Sensing, held during October 20-24, Malaysia. SABET SARVESTANI, M., LATIFI, I., KANAROGLOU, P. (2011), Three Decades of 
Urban Growth in the City of Shiraz, Iran: A Remote Sensing and Geographic Information Systems Application, Cities, 28, pp. 320 - 329.

SULLIVAN, W.,C., LOVELL, S.,T. (2006), Improving the Visual Quality of Commercial Development at the Rural-Urban Fringe, Landscape Urban Planning, 77, 1-2, pp.152-166.

WEST AZERBAIJAN'S ORGANIZATION for HOUSING and URBAN PLANNING (2006), Urmia's Economic and Social Development, Deputy for Coordination and Planning.

YU, XI, JUN, NG, NAM, CHO ( 2007), Spatial and Temporal Dynamics of Urban Sprawl Along two Urban-Rural Transects: A case study of Guangzhou, China, Landscape and Urban Planning, 79, pp. 96 - 109.

ZANGANEH SHAHRAKI, S, SAURI, D, SERRA, P., SEIFODDINI, F. (2011), Urban Sprawl Pattern and Land-use Change Detection in Yazd, Iran, Habitat International, 35, 4, pp. $521-528$.

ZHANG, T. (2000), Land Market and Government's Role in Sprawl, Cities, 17, 2, pp. 123-135.

Initial submission: 29.12.2011

Revised submission: 25.03.2012

Final acceptance: 31.05.2012

Correspondence: University of Isfahan, Department of Geography and Urban Planning, Geography Faculty, Isfahan, Iran.

E-mail: m_mobaraki_6@yahoo.com 
